\title{
JURNAL KESEHATAN
}

http://ejournal.poltekkesternate.ac.id

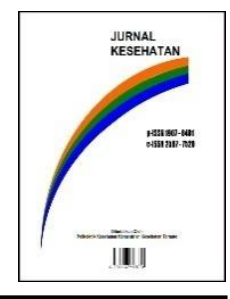

Pemanfaatan Cangkang Telur Puyuh Sebagai Pengikat Logam Berat Timbal (Pb) dalam Air

\author{
Wilda Faradila ${ }^{1}$, Anita Dewi Moelyaningrum ${ }^{2}{ }^{\bowtie}$ Rahayu Sri Pujiati $^{3}$ \\ ${ }^{123}$ Kesehatan Lingkungan dan Kesehatan Keselamatan Kerja, Fakultas Kesehatan \\ Masyarakat Universitas Jember, Indonesia \\ \anitamoelyani@gmail.com or anitadm@unej.ac.id \\ 081331914711
}

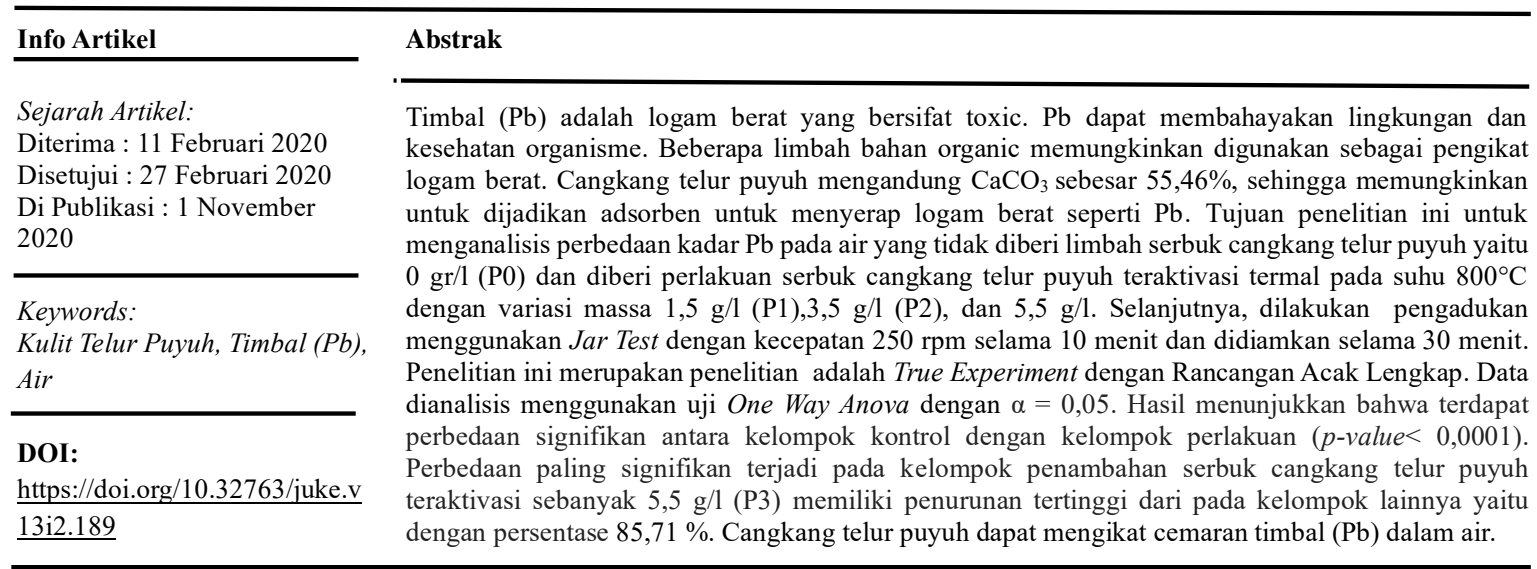

The Using Quails eggshell to Adsorb the Heavy Metal Lead $(\mathrm{Pb})$ in the Water.

\begin{abstract}
The lead $(\mathrm{Pb})$ is an toxic heavy metal. It can dangerous the environment human health. Organic waste material has been used as adsorbend. The quail eggshell has level of $\mathrm{CaCO} 3(55.46 \%)$ which can be used to adsorb heavy metals such as $\mathrm{Pb}$. The purpose of this study is to analyze the lead $(\mathrm{Pb})$ that contacted with activated quail egg shell powder at a temperature of $800^{\circ} \mathrm{C}$ with a mass variation of the adsorbent $0 \mathrm{gr} / 1(\mathrm{P} 0), 1.5 \mathrm{~g} / \mathrm{l}(\mathrm{P} 1), 3.5 \mathrm{~g} / 1(\mathrm{P} 2)$ and $5.5 \mathrm{~g} / \mathrm{l}(\mathrm{P} 3)$. They contacted with water that contain $\mathrm{Pb}$, then stired using a Jar Test at speed of $250 \mathrm{rpm}$ in 10 minutes let stand for 30 minutes. This study is True Experiment with completely randomized design. Data were analyzed using One Way Anova test with $\alpha=0,05$. The result showed that there were differences between the control groups and the treatment groups ( $p$-value $<0,0001$ ). The most significant differences occur in group with activated quail egg shell powder of $5.5 \mathrm{~g} / 1$ had the highest decrease of other groups, with the percentage of $85.71 \%$. The activated quail egg can adsorb lead $(\mathrm{Pb})$ in the water.
\end{abstract}

$\triangle$ Alamat korespondensi:

K3, Fakultas Kesehatan Masyarakat Universitas Jember, Indonesia

Email: anitamoelyani@gmail.com oranitadm@unej.ac.id

ISSN 2597-7520

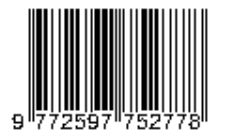

(C) 2020 Poltekkes Kemenkes Ternate 


\section{Pendahuluan}

Penimbunan sampah secara terus-menerus di Tempat Pemrosesan Akhir (TPA) Sampah dapat menghasilkan pencemar berupa air lindi (leachate). Cairan yang merembes melalui tumpukan sampah membawa materi terlarut atau tersuspensi terutama hasil proses dekomposisi materi sampah. Lindi memiliki potensi besar dalam mencemari badan air sekelilingnya, terutama air tanah di bawahnya. Masalah terberat dalam pengelolaan sampah adalah pencemaran air tanah.

Air Sumur monitoring Tempat Pemrosesan Akhir Sampah Pakusari, Jember mengandung logam berat timbal sebesar $0,164 \quad \mathrm{mg} / \mathrm{l}$ (Nindhianingtyas Widyasari, Moelyaningrum AD, \& Pujiati, 2011). Terdapat tiga sumur monitoring di TPA Pakusari, yang memiliki fungsi memantau kualitas air bersih yang berada di sekitar TPA Pakusari.

Logam berat timbal $(\mathrm{Pb})$ sumber pencemarannya dapat berasal dari alam ataupun aktivitas manusia yaitu dari bahan bakar, asap kendaraan, pipa air yang menggunakan timbal, kaleng makanan, cat, campuran keramik, udara, debu, pembuangan sampah dan berbagai industry seperti industry perak, baterai dan lain-lain. Keberadaan timbal di lingkungan dengan konsentrasi tinggi bisa saja berdampak pada kondisi kesehatan manusia. paparan $\mathrm{Pb}$ bisa menyebabkan gangguan sistem gastrointestinal, system reproduksi (penurunan libido, siklus menstruasi terganggu, keguguran pada kehamilan dan infertilitas pada laki-laki), system kardiovaskuler, system endokrin, penurunan IQ, gangguan syaraf. (Moelyaningrum AD, 2010)

Kandungan timbal $(\mathrm{Pb})$ yang tinggi pada darah juga mengakibatkan meningkatnya risiko osteoporosis (Moelyaningrum AD, 2016) dan meningkatkan risiko karies gigi (Moelyaningrum AD, 2016)

Penggunaan cangkang telur puyuh sebagai adsorben, dikarenakan banyak penelitian yang menggunakan adsorben alternatif yang berasal dari alam. Peneliti menggunakan cangkang telur puyuh sebagai adsorben karena lebih baik dari segi analisis biaya, daya adsorpsi dan jumlah adsorben. Bahan yang digunakan sebagai adsorben adalah limbah cangkang telur yang diaktivasi fisika sehingga dapat menambah daya serap adsorpsi (Atika, 2018).

Bahan organik terbukti dapat digunakan sebagai pengikat logam berat, seperti kulit kakao dapat menyerap logam berat timbal $(\mathrm{Pb})(\mathrm{AD}$ Moelyaningrum, 2018), ampas kopi dapat menyerap $\mathrm{Pb}$ (Moelyaningrum AD, 2018) sekaligus Cadmium (Baryatik P,. Moelyaningrum AD, Asihta, \& Nurcahyaningsih, 2019), kulit pisang kapok mampu mengikat $\mathrm{Pb}$ (Patracia,
Moelyaningrum, \& Pujiati, 2019). Cangkang kupang mampu menyerap logam berat kromium $\left(\mathrm{Cr}^{6+}\right)$ (Pridyanti, D. D., Moelyaningrum, A. D., \& Ningrum, 2018) dan kulit durian mampu menyerap logam berat kromium $\left(\mathrm{Cr}^{6+}\right)$ (Zarkasi \& Moelyaningrum, AD Ningrum, 2018).

Konsumsi telur puyuh di Indonesia mengalami kenaikan sebesar $16,4 \%$, berdasarkan data Susenas, rata-rata konsumsi produk peternakan per kapita per tahun 2015 - 2016 (Badan Pusat Statistik, 2017)

(Badan Pusat Statistik, 2017) Meningkatnya angka rata-rata konsumsi telur puyuh per tahun di Indonesia, membuat limbah cangkang telur puyuh juga akan semakin meningkat. Limbah cangkang telur puyuh apabila langsung dibuang ke lingkungan akan merusak estetika lingkungan, menambah volume sampah, bercampur dengan sampah lain dan berpotensi mencemari lingkungan. Cangkang telur bisa berpotensi menyebabkan polusi, hal ini disebabkan oleh aktivitas mikroba di lingkungan (Ardin, Karimuna, \& Amrullah Pagala, 2019)

Cangkang telur puyuh memiliki kadar $\mathrm{CaCO}_{3}$ $(55,46 \%)$, dan memiliki pori-pori mengandung asam protein mukopolisakarida yang dapat menjadi adsorben (Putri, 2012)

Beberapa ion logam divalent $\left(\mathrm{M}^{2+}\right)$ berinteraksi dengan $\mathrm{CaCO}_{3}$, kemudian ion logam dapat berkurang karena proses penyerapan yang terjadi (Aristia; Zulfadli; Khaldun, 2017)

Kandungan $\mathrm{CaCO}_{3}$ apabila dipanaskan menggunakan furnace maka akan menghasilkan senyawa pengaktif yaitu $\mathrm{CaO}$ yang merupakan komponen pengaktif digunakan sebagai pengadsorpsi senyawa toksik tersebut (Hartati, Riwayati, \& Kurniasari, 2011)

Adsorpsi dengan memanfaatkan berbagai jenis cangkang telur telah dilakukan oleh beberapa peneliti. Kemampuan adsorpsi dipengaruhi oleh salah satu faktor yaitu luas permukaan

Pada penelitian (Krisnawati Jasinda Iriany, 2013) tentang penyerapan $\mathrm{Cd}^{2+}$ menggunakan cangkang telur bebek menyebutkan bahwa pengikatan $\mathrm{Cd}^{2+}$ meningkat seiring dengan besarnya jumlah adsorben. Variasi jumlah adsorben adalah 0,5 gram, 1,0 gram dan 1,5 gram, hasil penelitian menunjukkan bahwa jumlah 1,5 g/l adsorben serbuk cangkang telur bebek dapat menurunkan logam berat $\mathrm{Cd}^{2+}$ sebesar 64,6667\%. Dalam penelitian (Susanto, T. N., Atmono., 2017) waktu titik jenuh logam berat terhadap adsorben terjadi pada menit ke 30. Serbuk cangkang telur puyuh akan dipanaskan pada suhu $800{ }^{\circ} \mathrm{C}$ untuk aktivasi termal. Cangkang telur yang diaktivasi dengan suhu $800{ }^{\circ} \mathrm{C}$ luas permukaannya 2700,978 $\mathrm{m}^{2} / \mathrm{g}$ (Krisnawati Jasinda Iriany, 2013).

VOL13 No $2 / 2020$ 
Pada penelitian ini bertujuan untuk menganalisis perbedaan kadar timbal $(\mathrm{Pb})$ antara kelompok kontrol P0 dengan kelompok air sumur yang diberi perlakuan serbuk cangkang telur puyuh dengan masing-masing variasi massa $1,5 \mathrm{~g} / 1,3,5 \mathrm{~g} / 1$ dan 5,5 g/l dikontakkan dengan $1000 \mathrm{ml}$ air sumur monitoring dengan waktu kontak 30 menit.

\section{Metode}

Penelitian ini merupakan penelitian True Experimental Design dengan bentuk Posstest-Only Control Design. Sampel air sumur penelitian ini berasal dari sumur monitoring TPA Pakusari Kabupaten Jember. Analisa kandungan $\mathrm{Pb}$ pada sampel di Balai Besar Laboratorium Kesehatan Surabaya. Penelitian dilakukan pada bulan Desember sampai dengan Mei 2019. Penelitian menggunakan Rancangan Acak Lengkap (RAL) non factorial yang terdiri dari 4 perlakuan dengan 6 kali pengulangan untuk masing-masing perlakuan. Kelompok kontrol (P0) yaitu air sumur mengandung $\mathrm{Pb}$ yang tidak diberi perlakuan penambahan massa serbuk cangkang telur puyuh teraktivasi termal. Kelompok perlakuan pertama (P1) adalah air sumur mangandung $\mathrm{Pb}$ yang diberi penambahan massa serbuk cangkang telur puyuh teraktivasi termal 1,5 g/l, kelompok perlakuan kedua (P2) adalah air sumur mangandung $\mathrm{Pb}$ yang diberi penambahan massa serbuk cangkang telur puyuh teraktivasi termal 3,5 g/l, dan kelompok perlakuan ketiga (P3) adalah air sumur mangandung $\mathrm{Pb}$ yang diberi penambahan massa serbuk cangkang telur puyuh teraktivasi termal 1,5 g/l. Lama waktu kontak selama 30 menit dan total sampel sebanyak 24 sampel.

Tahap penelitian adalah mempersiapkan cangkang telur puyuh, pembuatan serbuk cangkang telur puyuh, aktivasi serbuk cangkang telur puyuh secara termal, pengambilan air sumur mengandung $\mathrm{Pb}$, pengontakan serbuk cangkang telur puyuh teraktivasi termal dengan air sumur mengandung $\mathrm{Pb}$, pengukuran analisa data dan hasil penelitian. Alat-alat yang digunakan dalam penelitian ini adalah Gelasukur, Neracaanalitik, Corong Buchner, Ayakan 100 mesh, Blender Stopwatch, Furnace, Gelas beaker, Jar Test, dan Kertassaring. Pemeriksaan pada air dilakukan dengan menggunakan metode AAS (Atomic Absorption Spectrophometer).

Teknik pengumpulan data adalah pengukuran. Teknik analisis data menggunakan analisis deskriptif dan analitik. Uji ststistik yang dilakukan adalah normalitas dengan Kolmogorov smirnov, homogenitas dan uji perbedaan dengan One Way anova. Kelompok yang memiliki perbedaan paling signifikan dapat diketahui dengan uji Post Hoc.

\section{Hasil}

Berdasarkan hasil uji laboratorium pada kelompok kontrol dan kelompok perlakuan dapat dilihat pada gambar 1. Berdasarkan grafik 1 menunjukkan bahwa rata-rata hasil uji logam timbal $(\mathrm{Pb})$ pada kelompok kontrol air sumur TPA Pakusari melebihi baku mutu air sebesar 0,07 mg/l.

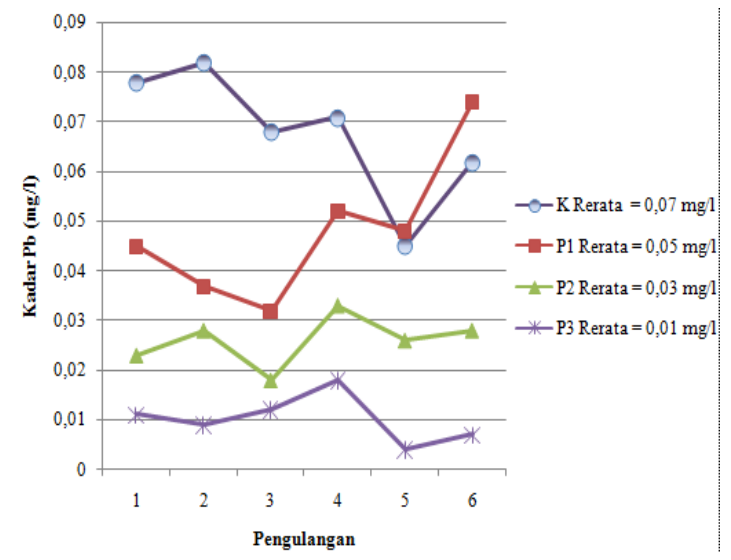

Sedangkan pada kelompok perlakuan terjadi penurunan setelah dikontakkan dengan serbuk cangkang telur puyuh teraktivasi termal, yang ditandai dengan kenaikan efisiensi penyerapan seiring bertambahnya massa serbuk cangkang telur puyuh teraktivasi termal. Pada kelompok perlakuan dengan penambahan massa serbuk cangkang telur puyuh sebanyak $1,5 \mathrm{gr}, 3,5$ gr dan 5,5 gr berturutturut didapatkan rata-rata penurunan sebesar 0,05 $\mathrm{mg} / \mathrm{l}, 0,03 \mathrm{mg} / \mathrm{l}$ dan $0,01 \mathrm{mg} / \mathrm{l}$. Hasil nilai pada kelompok kontrol dan kelompok perlakuan dengan penambahan cangkang telur puyuh sebanyak $1,5 \mathrm{gr}$ masih melebihi baku mutu air bersih yaitu 0,05 mg/l. Berikut merupakan data penurunan kadar timbal $(\mathrm{Pb})$ pada tabel 1 .

Tabel 1. Rata-rata dan Persentase Penurunan Kadar $\mathrm{Pb}$

\begin{tabular}{ccc}
\hline $\begin{array}{c}\text { Kelompok } \\
\text { Perlakuan }\end{array}$ & Mean $(\mathrm{mg} / \mathrm{l})$ & $\begin{array}{c}\text { Penurunan } \\
\text { Kadar } \mathrm{Pb}(\%)\end{array}$ \\
\hline $\mathrm{K}$ & 0,07 & - \\
$\mathrm{P} 1$ & 0,05 & 28,57 \\
$\mathrm{P} 2$ & 0,03 & 57,14 \\
$\mathrm{P} 3$ & 0,01 & 85,71 \\
\hline
\end{tabular}

Sumber: Data Primer

Hasil analisis uji One Way Anova menunjukkan bahwa nilai p lebih kecil dari 0,05 yang dapat diartikan bahwa terdapat perbedaan signifikan penurunan kadar timbal $(\mathrm{Pb})$ antara kelompok kontrol dengan kelompok P1, kelompok P2 dan kelompok P3.

Tabel 2. Hasil Uji pos hoc 


\begin{tabular}{ccccc}
\hline $\begin{array}{c}\text { Perla } \\
\text { kuan }\end{array}$ & K & P1 & P2 & P3 \\
\hline K & - & $0,019^{*}$ & $0,000^{*}$ & $0,000^{*}$ \\
P1 & $0,019^{*}$ & - & $0,008^{*}$ & $0,000^{*}$ \\
P2 & $0,000^{*}$ & $0,008^{*}$ & - & 0,072 \\
P3 & $0,000^{*}$ & $0,000^{*}$ & 0,072 & - \\
\hline
\end{tabular}

Sumber: Data Primer

Hasil uji pos hoc pada tabel 2 menjelaskan bahwa penurunan kadar timbal $(\mathrm{Pb})$ berbeda paling signifikan antar kelompok kontrol $(\mathrm{K})$ dengan kelompok perlakuan kedua $(\mathrm{P} 2)$ yaitu $p=0,000$ dan perlakuan ketiga (P3) $p=0,000$ dibandingkan kelompok perlakuan pertama.

Hasil analisa laboratorium kadar timbal $(\mathrm{Pb})$ pada air sumur adalah $0,07 \mathrm{mg} / 1$ yang menunjukkan bahwa air sumur di sekitar TPA Pakusari Jember mengandung logam berat timbal $(\mathrm{Pb})$ yang tidak memenuhi Peraturan Menteri Kesehatan No. 32 Tahun 2017 tentang Standar Baku Mutu Kesehatan Lingkungan dan Persyaratan Kesehatan Air untuk Keperluan Higiene sanitasi, Kolam Renang, Solus Per Aqua, dan Pemandian Umum yaitu sebesar 0,05 $\mathrm{mg} / \mathrm{l}$. Sehingga air sumur perlu di kelola terlebih dahulu sebelum digunakan masyarakat agar kadar timbal $(\mathrm{Pb})$ menjadi dibawah ambang baku mutu yang ditetapkan. Penurunan kadar timbal $(\mathrm{Pb})$ dapat dilakukan dengan menggunakan bahan adsorben seperti memanfaatkan limbah cangkang telur puyuh.

\section{Pembahasan}

Hasil penelitian ini menunjukkan bahwa serbuk cangkang telur puyuh teraktivasi termal mampu menurunkan kadar timbal $(\mathrm{Pb})$ pada air sumur. Penurunan kadartimbal $(\mathrm{Pb})$ dengan penambahan massa adsorben 1,5 g/1, 3,5 g/1 dan 5,5 $\mathrm{g} / 1$ berturut-turut yaitu sebesar $28,57 \%, 57,14 \%$ dan $85,71 \%$. Kemampuan penurunan kadar timbal $(\mathrm{Pb})$ dipengaruhi beberapa faktor seperti massa adsorben, karakteristik adsorbat, luas permukaan adsorben, temperature, kemampuan adsorben dan waktu kontak.

Massa adsorben berpengaruh terhadap besar penurunan logam timbal $(\mathrm{Pb})$ yang terjadi. Massa adsorben yang semakin besar dapat menambah luas permukaan adsorbennya. Sesuai dengan penelitian (Krisnawati, Jasinda, Iriany, 2013) tentang penyerapan $\mathrm{Cd}^{2+}$ dan $\mathrm{Pb}$ dalam penelitiannya menunjukkan bahwa seiring dengan besarnya massa serbuk cangkang telur bebek yang digunakan, maka efisiensi penyerapan terhadap ion logam $\mathrm{Cd}^{2+}$ dan $\mathrm{Pb}$ semakin besar. Penelitian yang dilakukan oleh (DD Pridyanti, Moelyaningrum AD, PT Ningrum, 2018) terkait adsorpsi kromium $\left(\mathrm{Cr}^{2+}\right)$ menggunakan cangkang kupang menunjukkan penyerapan logam yang semakin tinggi seiring dengan penambahan massa serbuk cangkang kupang. Penelitian (Ratnasari, Moelyaningrum AD, \& Ellyke, 2017) yang menunjukkan penambahan massa serbuk cangkang telur ayam potong teraktivasi termal maka semakin besar penyerapan terhadap logam $\mathrm{Cu}$ pada limbah cair industri elektroplating.

\section{(1) Pengaruh Kemampuan Adsorben}

Cangkang telur puyuh dijadikan sebagai adsorben dikarenakan mempunyai kendungan $\mathrm{CaCO}_{3}$ (Kalsium Karbonat) yang tinggi yaitu 55,46\% (Atika, 2018). Kalsium karbonat $\left(\mathrm{CaCO}_{3}\right)$ adalah bahan yang sesuai yang digunakan untuk penghilang senyawa toksik seperti limbah logam berat. Kalsium karbonat $\left(\mathrm{CaCO}_{3}\right)$ secara fisik pada bagian dalam kutikula terdapat Kristal hidroksiapatit yang memiliki pori-pori mengandung asam protein mukopolisakarida. Asam protein mukopolisakarida dikembangkan menjadi suatu adsorben dan berperan sebagai senyawa aktif dalam proses adsorpsi.

Dekomposisi termal $\mathrm{CaCO}_{3}$ menjadi $\mathrm{CaO}$ dapat dilakukan pada suhu $500-1000^{\circ} \mathrm{C}$ (Mohamed, Yousuf, \& Maitra, 2016). Penelitian yang dilakukan (Asleni, Itnawita, GF Kartika, 2016) menunjukkan semakin banyak waktu kalsinasi kemampuan cangkang kerang darah dalam mengadsorpsi juga semakin terhadap kation dan anion juga akan semakin besar. Dan juga kerangka $\mathrm{CaO}$ yang semakin besar, maka luas permukaan aktif akan semakin besar pula sehingga kemampuan adsorpsi lebih tinggi.

\section{(2) Ukuran Adsorben}

Semakin kecil ukuran partikel dan semakin berpori suatu material adsorben maka nilai adsorpsi akan semakin meningkat. Ukuran partikel yang kecil akan mengakibatkan penyerapan adsorben lebih baik karena besarnya tenaga inter molekular yang dimiliki (Istigfarini SAE S.Daud Edwad Hs, 2017). Semakin kecil ukuran partikel adsorben, maka luas permukaan akan semakin besar. Penelitian yang dilakukan (Syafrianda I E Yenie S Daud, 20017). Penelitian (Shafrinia, Rahma; Wardana, Irawan Wisnu;, 2016) menunjukkan bahwa penyisihan tertinggi pada air limbah terjadi pada ukuran media yang 100 mesh yaitu sebesar $71,6 \%$ daripada ukuran media 10 dan 40 mesh.

\section{(3) Kecepatan Pengadukan}

Proses pengadukan ini dilakukan agar penyerapan logam merata dan tidak menggumpal pada satu tempat saja,dan menyebabkan penyerapan logam tidak optimal. Pada proses adsorpsi kecepatan pengadukan merupakan parameter penting, karena apabila pengadukan terlalu cepat kemungkinan besar struktur adsorben 
cepat rusak sehingga proses adsorpsi kurang optimal (Syafrianda I E Yenie S Daud, 20017). Penelitian yang dilakukan (Sirajuddin, Syahrir Muhammad, 2017) hasil analisis pengaruh kecepatan pengadukan terhadap penurunan surfaktan pada limbah laundry terbesar pada kecepatan pengadukan $250 \mathrm{rpm}$ sebesar 80,39\%.

\section{(4) Waktu Kontak}

Waktu kontak yang ditentukan untuk adsorpsi berfungsi untuk menghasilkan kapasitas adsorpsi maksimum pada waktu kesetimbangan. Peneliti menggunakan waktu kontak selama 30 menit yang diperoleh dari penelitian (Susanto, T. N., Atmono., 2017) menunjukkan bahwa pada menit ke-30 kadar kromium $(\mathrm{Cr})$ mengalami penurunan paling besar dengan persentase $48,01 \%$. Variasi waktu yang digunakan adalah 10, 20, 30, 40 dan 60 menit. Pada menit ke-30 menunjukkan bahwa terjadi kesetimbangan kecepatan adsorpsi adsorpsi lebih besar daripada desorpsi, sedangkan pada menit ke40 dan 60 kemampuan adsorben menurunan.

\section{Kesimpulan dan Saran}

Nilai rata-rata kadartimbal $(\mathrm{Pb})$ pada kelompok kontrol (P0), P1, P2, dan P3 berturutturut adalah $0,07 \mathrm{mg} / \mathrm{l} ; 0,05 \mathrm{mg} / \mathrm{l} ; 0,03 \mathrm{mg} / \mathrm{l}$; dan $0,01 \mathrm{mg} / \mathrm{l}$. Penurunan kadar timbal $(\mathrm{Pb})$ pada kelompok penambahan serbuk cangkang telur puyuh pada kelompok perlakuan P1, P2 dan P3 berturut-turut yaitu $28,57 \%, 57,14 \%$ dan $85,71 \%$. Terdapat perbedaan penurunan kadar timbal $(\mathrm{Pb})$ yang signifikan antar kelompok kontrol (P0) dan kelompok perlakuan penambahan massa serbuk cangkang telur puyuh P1 $(1,5 \mathrm{~g} / \mathrm{l})=0,019 ; \mathrm{P} 2(3,5$ $\mathrm{mg} / \mathrm{l})=0,000 ; \mathrm{P} 3(5,5 \mathrm{mg} / \mathrm{l})=0,000$.

Perlu penelitian lebih lanjut untuk control variable lainnya, seperti tegangan permukaan dan konsentrasi adsorbat sehingga diperoleh kondisi adsorpsi yang optimum untuk mendapatkan serapan yang optimum terhadap logam besar. Penggunaan serbuk cangkang telur puyuh yang teraktivasi termal sebanyak $3,5 \mathrm{~g} / 1$ dapat dijadikan alternative untuk mengikat logam berat timbal $(\mathrm{Pb})$ pada air sumur sekitar TPA Pakusari. Sehingga peneliti selanjutnya juga dapat membuat filter air, hasil serbuk cangkang telur puyuh teraktivasi bias diterapkan langsung dengan mengetahui takaran serbuk cangkang telur puyuh teraktivasi untuk takaran bak air atau pada volume air sumur tersebut.

Pengaplikasian filter air dapat dilakukan pada air sumur di pemukiman sekitar TPA Pakusari yang kemungkinan tercemar oleh logam berat. Jarak penyebaran bahan pencemar kimia dapat mencapai 95 meter dari sumbernya Filter air menggunakan serbuk cangkang telur puyuh teraktifasi termal dapat dijadikan alternative untuk mengelola air sumur yang tercemar logam berat timbal.

\section{Daftar Pustaka}

Ardin, L., Karimuna, L., \& Amrullah Pagala, M. (2019). Formulasi Tepung Cangkang Telur dan Tepung Beras Merah Terhadap Nilai Kalsium dan Organoleptik Kue Karasi [Effect of Eggshell Flour and Red Rice Flour Formulation on Calcium Content and Organoleptic Properties of Karasi Cake]. $J$. Sains Dan Teknologi Pangan, 4(1), 18921904.

Aristia; Zulfadli; khaldun. (2017). Uji Daya Serap Serbuk Gergaji Kayu Damar Laut ( Shorea $\mathrm{sp}$ ) Terhadap Logam $\mathrm{Pb}$ ( II ) Abstrak Pendahuluan Metode Penelitian Prosedur Penelitian. Jurnal Ilmiah Mahasiswa Pendidikan Kimia, 4(4), 166-175.

Asleni Itnawita GF Kartika. (2016). Potensi Abu Cangkang Kerang Darah (Anadara granosa) Dengan Variasi Waktu Kalsinasi Sebagai Adorbent Ion $\mathrm{Cu} 2+$, $\mathrm{Sn} 2+$, $\mathrm{CN}$ - dan NO3-. Universitas Riau. Retrieved from http://repository.unri.ac.id/

Atika, N. (2018). Penurunan kadar ion kromium (vi) dalam air menggunakan serbuk cangkang telur puyuh. Universitas Muhammadiyah Semarang.

Badan Pusat Statistik. (2017). Survei Sosial Ekonomi Nasional. Retrieved from https :// BPS.go.id

Baryatik, P., Moelyaningrum, A. D., Asihta, U., \& Nurcahyaningsih, W. (2019). Pemanfaatan Arang Aktif Ampas Kopi sebagai Adsorben Kadmium pada Air Sumur. Jurnal Teknologi Lingkungan Lahan Basah, 02(1), 011-019.

DD Pridyanti AD Moelyaningrum PT Ningrum. (2018). Pemanfaatan Limbah Cangkang Kupang (Corbula Faba) Teraktivasi Termal Sebagai Adsorben Logam Kromium (Cr6+) Pada Limbah Cair Batik. Jurnal Hibualamo Seri Ilmu Ilmu Alam Dan Kesehatan, 2(2), 78-83.

Hartati, I., Riwayati, I., \& Kurniasari, L. (2011). Potensi xanthate pulpa kopi sebagai adsorben pada pemisahan ion timbal dari limbah industri batik. Momentum, 7(2), 25-30.

Istigfarini SAE S.Daud Edwad Hs. (2017). Pengaruh Massa dan Ukuran Partikel Adsorben Sabut Kelapa Terhadap Efisiensi Penyisihan Fe Pada Air Gambut. Jom 
FTEKNIK, 2(1), 1-17.

Krisnawati Jasinda Iriany. (2013). Penyerapan Logam Kadmium (Cd 2+) Dengan Adsorben Cangkang Telur Bebek Yang Telah Diaktivasi. Jurnal Teknik Kimi USU, 2(3), 29-32.

Moelyaningrum AD. (2018). The Potential of Cacao Pod Rind Waste (Theobroma cacao) to Adsorb Heavy Metal $(\mathrm{Pb}$ and $\mathrm{Cd})$ in Water. In Sustainable Future for Human Security. Springer, Singapore (pp. 265-276). Singapore: Springer Berlin Heidelberg. https://doi.org/https://doi.org/10.1007/978981-10-5433-4_18

Moelyaningrum AD. (2010). Timah Hitam dan Kesehatan.pdf. Jurnal IKESMA, 6(2), 110122. Retrieved from https://jurnal.unej.ac.id/index.php/IKESMA/ article/view/1626

Moelyaningrum AD. (2016a). Correlation Between Blood Lead Level (BLL) And Osteoporosis in Postmenopausal Women In Surabaya Indonesia Anita Dewi Moelyaningrum. In The 1st International Symposium of Public Health "Emerging and Re-emerging Diseases. (pp. 190-197). https://doi.org/DOI 10.17605/OSF.IO/UC7WP

Moelyaningrum AD. (2016b). Timah Hitam (Pb) dan Karies Gigi. Stomatognatic. Jurnal Kedokteran Gigi, 13(1), 28-31.

Moelyaningrum AD. (2018). The Robusta Coffee Grounds Residues to Adsorb the Heavy Metal Lead $(\mathrm{Pb})$ in the Water. In Journal of Physics: Conference Series (Vol. 1114, p. 012058). https://doi.org/10.1088/17426596/1114/1/012058

Mohamed, M., Yousuf, S., \& Maitra, S. (2016). Study of calcinations condition on decomposition of calcium carbonate in waste cockle shell to calcium oxide using thermal gravimetric analysis. Journal of Engineering Science and Technology, 11(16), 9917-9921.

Patracia, D., Moelyaningrum, A. D., \& Pujiati, R. S. (2019). Arang Aktif Kulit Pisang Kepok Dalam Mengikat Logam Berat Timbal. Jurnal Berkala Kesehatan, 5(1), 18. https://doi.org/10.20527/jbk.v5i1.5939

Pridyanti, D. D., Moelyaningrum, A. D., \& Ningrum, P. T. (2018). Pemanfaatan Limbah Cangkang Kupang Teraktivasi Termal Sebagai Adsorben Logam Kromium (Cr6+) Pada Limbah Cair Batik. Seri Ilmu-Ilmu Alam Dan Kesehatan, 2(2), 69-77.
Putri, A. A. M. (2012). Metode Single Drop Pada Pembuatan. Institut Pertanian Bogor.

Ratnasari, N.D, Moelyaningrum, AD \& Ellyke. (2017). Penurunan Kadar Tembaga (Cu) Pada Limbah Cair Industri Elektroplating Menggunakan Cangkang Telur Ayam Potong Teraktivasi Termal. Jurnal Kesehatan Lingkungan, $\quad 09, \quad 56-62$. https://doi.org/http://dx.doi.org/10.29238/sa nitasi.v9i2.65

Shafrinia, Rahma; Wardana, Irawan Wisnu;, wiharyanto O. (2016). Pengaruh Variasi Ukuran Adsorben dan Debit Aliran Terhadap Penururnan Khrom (Cr) dengan Arang Aktif dari Limbah Kulit Pisang pada Limbah Cair Industri Pelapisan Logam (Elektroplating) Krom. Teknik Lingkungan, 5(1), 1689-1699. https://doi.org/10.1017/CBO9781107415324 .004

Sirajuddin, Syahrir Muhammad, S. I. (2017). Optimasi Kecepatan Pengadukan Pada Proses Adsorpsi Limbah Cair Laundry Untuk Menurunkan Kadar Surfaktan Menggunakan Batu Bara. Seminar Nasional Sains Dan Teknologi, (November), 1-2.

Susanto, T. N., Atmono., N. (2017). Pemanfaatan Limbah Cangkang Telur Ayam Sebagai Media Adsorben dalam Penurunan Kadar Logam Kromium Heksavalen $(\mathrm{Cr} 6+)$ pada Limbah Cair Industri Elektroplating. Ecolab, 11(1), 27-31.

Syafrianda I E Yenie S Daud. (20017). Pengaruh Waktu Kontak dan Laju Pengadukan Terhadap Adsorpsi Zat Warna Pada Air Gambut Menggunakan Adsorben Limbah Biosolid Land Application Industri Minyak Kelapa Sawit. Jom FTEKNIK, 4(2), 1-6.

Widyasari, N., Moelyaningrum, A., \& Pujiati, R. S. (2011). Analisis Potensi Pencemaran Timbal ( $\mathrm{Pb}$ ) Pada Tanah, Air Lindi Dan Air Tanah ( Sumur Monitoring ) Di TPA Pakusari Kabupaten Jember. Skripsi.FKM Universitas Jember.

Zarkasi, K., \& Moelyaningrum, AD Ningrum, P. T. (2018). Penggunaan Aranga Aktif Kulit Durian ( Durio zibethinus Murr ) Terhadap Tingkat Adsorpsi Kromium ( $\mathrm{Cr} 6+$ ) Pada Limbah Batik. Effektor, 5(2), 67-73. 